\title{
Attempted Predation on a Smooth-scaled Worm Lizard, Gymnophthalmus underwoodi (Grant 1958) by a Rainbow Whiptail, Cnemidophorus lemniscatus (Linnaeus 1758) in Suriname
}

Rawien Jairam

Vertebrate Department, National Zoological Collection of Suriname, Anton de Kom University, Leysweg-86, Suriname (rawien_2000@yahoo.com)

$\mathrm{T}$ he lizard genus Cnemidophorus (Wagler 1830) comprises sixteen currently recognized species (Harvey et al. 2012). The Rainbow Whiptail (Cnemidophorus lemiscatus) ranges throughout much of Central and northern South America. Most prey items taken by $C$. lemniscatus are invertebrates (Hoogmoed 1973; Avila Pires 1995), but plant material (Vitt et al. 1997; Mijares-Urrutia et al. 1997), including fruits (Vitt and Carvalho 1995; Vitt et al. 1997), also are consumed. Although the diet might vary seasonally (Mesquita and Colli 2003), I found no record of C. lemniscatus taking any vertebrate prey.

I herein document the first observed predation attempt by $C$. lemniscatus on a Smooth-scaled Worm Lizard (Gymnophthalmus underwoodi) on Tonka Island $\left(4^{\circ} 55^{\prime} \mathrm{N}\right.$, $\left.55^{\circ} 07^{\prime} \mathrm{W}\right)$, located in the Professor Dr. Ir. W. J. van Blommenstein Lake in Suriname. The van Blommenstein Lake, more commonly referred to as Lake Brokopondo due to its location in the district of Brokopondo, is one of the oldest reservoirs in the tropics (Van der Heide 1982; Mol et al. 2007). The Brokopondo Lake has a surface area of approximately $1,600 \mathrm{~km}^{2}$ and contains approximately 1,100 islands (Van der Heide 1982), although this number varies when high water levels "create" new islands or low levels connect islands close to shore with the mainland. Tonka Island, which has been isolated from the mainland for approximately 52 years, is a well-known tourist destination. In addition to accommodating tourists, its owner, Frits van Troon, actively promotes biodiversity-related research. The presence of basic accommodations, a relatively short distance from the capital, and a diversity of habitats make it an ideal location for students.

During a fieldtrip in April 2016, I led a group of five students conducting a survey of the herpetofauna on the grounds. We noticed a C. lemniscatus apparently disturbed by us walking through the trimmed grass field. Closer inspection revealed that it had something in its mouth that was still

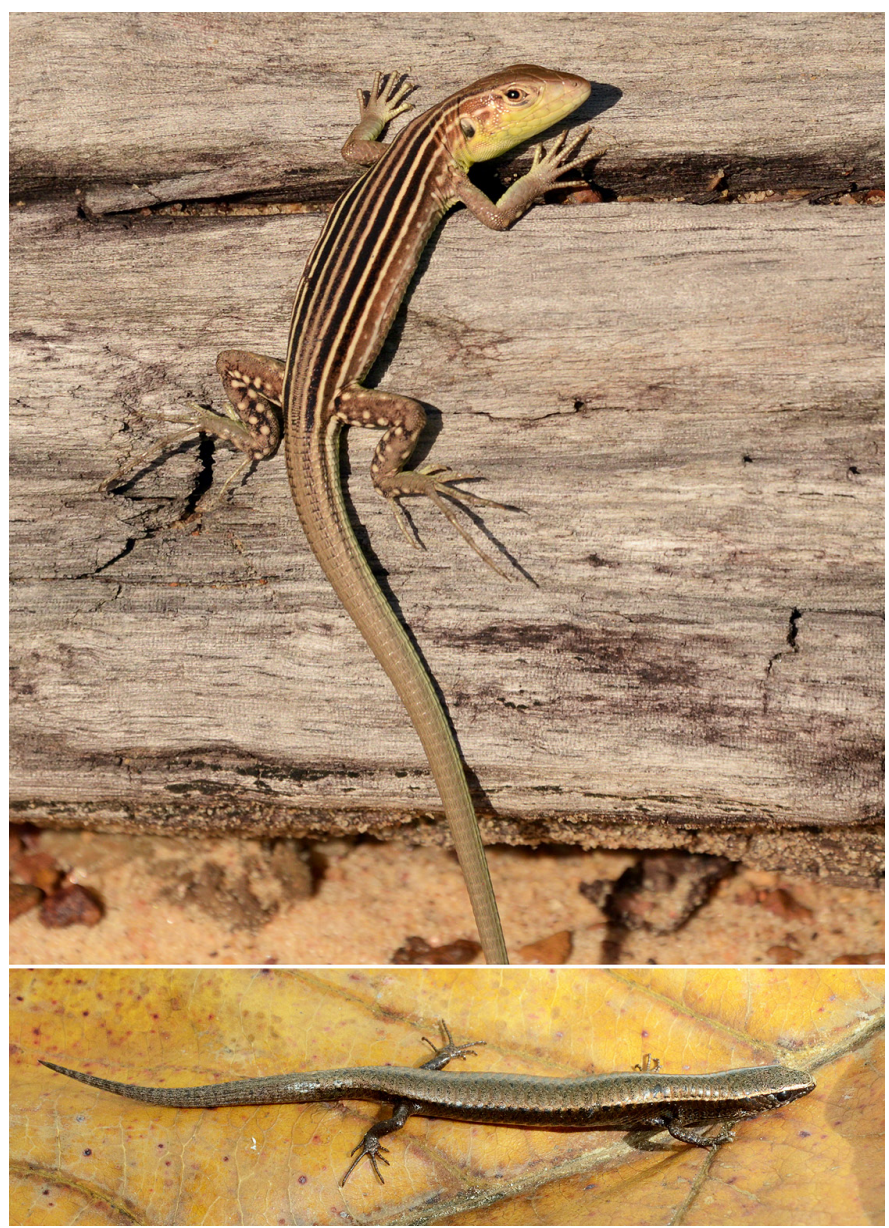

Fig. 1. A Rainbow Whiptail (Cnemidophorus lemniscatus; top) and a Smooth-scaled Worm Lizard (Gymnophthalmus underwoodi) from Tonka Island, Suriname. 
moving. Approaching carefully, we identified the object as a G. underwoodi, a species we had already documented during the morning survey. Although we retreated quietly, the $C$. lemniscatus, disturbed by our presence, shook the captured $G$. underwoodi a few times and then released it. I captured the $C$. lemniscatus and, after some searching in the grass, spotted the G. underwoodi, which was collected by one of the students. Unfortunately, photographs taken of the C. lemniscatus with the $G$. underwoodi in its mouth failed to show the predation attempt due to distance and the inadequacies of our simple camera. After completion of the survey, I placed both individuals in a container hoping that the C. lemniscatus would resume its efforts to catch the $G$. underwoodi, but apart from biting it a few times, which might have occurred due to the stress of confinement, we observed no other predatory behaviors. Both specimens were euthanized, fixed in $4 \%$ formalin in the field, subsequently transferred to $70 \%$ ethanol, and accessioned in the National Zoological Collection of Suriname (NZCS) as NZCS R683-684.

One possible explanation for the selection of $G$. underwoodias prey by $C$. lemniscatus would be the relative abundance of the former on Tonka Island. During the two-hour survey, which covered an area of approximately 3.4 ha, we counted 22 C. lemniscatus and 15 G. underwoodi (Fig. 1). The only other lizard species observed were Giant Ameivas (Ameiva ameiva), introduced Tropical House Geckos (Hemidactylus mabouia), and Mourning Geckos (Lepidodactylus lugubris). An analysis of the stomach contents of the C. lemniscatus specimen revealed only a few invertebrates. Additional examination of stomach contents of $C$. lemniscatus and $A$. ameiva might determine whether or not this predation attempt was an isolated event.

\section{Acknowledgments}

I thank the MSc students of the Institute for Graduate Studies and Research (IGSR) who participated in the survey and kindly provided information on the relative abundance of C. lemniscatus and G. underwoodi observed during their survey. Vanessa Kadosoe provided the photograph of C. lemniscatus in Figure 1.

\section{Literature Cited}

Avila-Pires, T.C.S. 1995. Lizards of Brazilian Amazonia (Reptilia: Squamata). Zoologische Verhandelingen 299: 1-706.

Harvey, M.B., G.N. Ugueto, and R.L. Gutberlet, Jr. 2012. Review of teiid morphology with a revised taxonomy and phylogeny of the Teiidae (Lepidosauria: Squamata). Zootaxa 3459: 1-156.

Hoogmoed, M.S. 1973. Notes on the Herpetofauna of Surinam IV: The lizards and amphisbaenians of Surinam. Biogeographica 4: 1-419.

Mesquita, D.O. and G.R. Colli. 2003. Geographical variation in the ecology of populations of some Brazilian species of Cnemidophorus (Squamata, Teiidae). Copeia 2003: 285-298.

Mijares-Urrutia, A., B. Colvee, and R.A. Arends. 1997. Cnemidophorus lemniscatus (NCM). Herbivory. Herpetological Review 28: 88.

Mol, J.H., B.D. Mérona, P.E. Ouboter, and S. Sahdew. 2007. The fish fauna of Brokopondo Reservoir, Suriname, during 40 years of impoundment. Neotropical Ichthyology 5: 351-368.

Van der Heide, J. 1982. Lake Brokopondo: Filling Phase Limnology of a Man-made Lake in the Humid Tropics. Kanters, Alblasserdam, The Netherlands.

Vitt, L.J. and C.M. de Carvalho. 1995. Niche partitioning in a tropical wet season: Lizards in the lavrado area of northern Brazil. Copeia 1995: 305-329.

Vitt, L.J., P.A. Zani, J.P. Caldwell, M.C. de Araujo, and W.E. Magnusson. 1997. Ecology of whiptail lizards (Cnemidophorus) in the Amazon region of Brazil. Copeia 1997: 745-757. 